\title{
Pengaruh Kecerdasan Emosional, Kecerdasan Spiritual, dan Perilaku Belajar Pada Tingkat Pemahaman Akuntansi
}

\author{
Ida Ayu Clara Agustin ${ }^{1}$ \\ I Ketut Sujana ${ }^{2}$
}

\author{
${ }^{1}$ Fakultas Ekonomi dan Bisnis Universitas Udayana (Unud), Bali, Indonesia \\ email: claraagustin1608@gmail.com/ Telp: +6285936122901 \\ ${ }^{2}$ Fakultas Ekonomi dan Bisnis Universitas Udayana (Unud), Bali, Indonesia
}

\begin{abstract}
ABSTRAK
Pemahaman akuntansi merupakan suatu proses seorang mahasiswa akuntansi dalam memahami hal-hal yang terkait dengan akuntansi. Pemahaman akuntansi mahasiswa tidak hanya ditunjukkan dari nilai-nilai yang didapatkannya dalam mata kuliah tetapi juga dipengaruhi oleh beberapa faktor. Tujuan penelitian ini adalah untuk mengetahui pengaruh kecerdasan emosional, kecerdasan spiritual, dan perilaku belajar pada tingkat pemahaman akuntansi pada mahasiswa non reguler jurusan akuntansi angkatan 2014 di Fakultas Ekonomi dan Bisnis Universitas Udayana. Metode penentuan sampel penelitian ini menggunakan metode purposive sampling dengan menggunakan rumus slovin. Pengumpulan data menggunakan kuesioner yang disebarkan langsung kepada mahasiswa sebanyak 126 kuesioner. Teknik analisis data yang digunakan adalah regresi linear berganda. Hasil penelitian menunjukkan bahwa kecerdasan emosional, kecerdasan spiritual, dan perilaku belajar berpengaruh positif pada tingkat pemahaman akuntansi.

Kata kunci: pemahaman, emosional, spiritual, perilaku belajar
\end{abstract}

\begin{abstract}
Accounting understanding is a process of an accounting student in understanding matters related to accounting. Students' accounting understanding is not only shown from the values obtained in the course but also influenced by several factors. The purpose of this study was to determine the effect of emotional intelligence, spiritual intelligence, and learning behavior on the level of understanding of accounting for non-regular students of the 2014 accounting department at the Faculty of Economics and Business at Udayana University. The method of determining the sample of this study uses purposive sampling method using the Slovin formula. Data collection using questionnaires distributed directly to students as many as 126 questionnaires. The data analysis technique used is multiple linear regression. Based on the results shows that emotional intelligence, spiritual intelligence, and learning behavior have a positive effect on the level of understanding of accounting.
\end{abstract}

Keywords: understanding, emotional, spiritual, learning behavior

\section{PENDAHULUAN}

Era globalisasi saat ini, pendidikan menjadi peranan yang sangat penting dan menjadi tolak ukur yang dapat menentukan maju atau mundurnya proses pembangunan negara. Pendidikan merupakan awal dari terbentuknya tingkah laku, mental, dan kepribadian seseorang. Perguruan tinggi merupakan jenjang 
Ida Ayu Clara Agustin dan I Ketut Sujana. Pengaruh...

pendidikan tertinggi dalam sistem pendidikan nasional Indonesia. Di perguruan tinggi dapat menciptakan individu yang berkualitas sehingga mampu mengubah masa depan bangsa menjadi lebih baik. Terdapat hal yang harus diperhatikan untuk menciptakan mahasiswa yang berkualitas yang dapat memahami pelajaran yang diberikan oleh dosen, terutama dalam hal sistem pengajaran di ruangan dalam bobot pelajaran yang disampaikan.

Mahasiswa harus berkonsentrasi pada materi pembelajaran yang diberikan oleh dosen di ruang kelas. Konsentrasi belajar merupakan suatu perhatian khusus yang biasanya dilakukan pada saat mulai proses belajar di kelas, ataupun melakukan suatu kegiatan belajar di luar kelas. Kurangnya konsentrasi belajar sangat memengaruhi hasil belajar yang dicapai. Dalam aktivitas belajar mengajar di kelas, mahasiswa seharusnya berkonsentrasi penuh pada materi yang dijelaskan dosen untuk mendapatkan hasil yang memuaskan. Dengan adanya konsentrasi penuh, mahasiswa akan memahami materi mata kuliah yang diajarkan. Masalah yang biasa dihadapi seorang mahasiswa yang menyebabkan berkurangnya konsentrasi belajar adalah kurangnya manajemen waktu, kondisi kesehatan, kurang minat terhadap mata kuliah, adanya masalah pribadi atau masalah keluarga, dan cara penyampaian materi oleh dosen. Faktor masalah tersebut akan berdampak negatif untuk mahasiswa itu sendiri (Abed,2012).

Pendidikan akuntansi khususnya pendidikan tinggi akuntansi yang diselenggarakan di perguruan tinggi ditujukan untuk mendidik mahasiswa agar dapat bekerja sebagai seorang akuntan profesional yang memiliki pengetahuan dibidang akuntansi. Menurut Phillips (2007) pendidikan akuntansi yang diajarkan 
di perguruan tinggi hanya terkesan sebagai pengetahuan yang berorientasi pada mekanisme secara umum saja, sangat berbeda apabila dibandingkan dengan praktik sesungguhnya yang dihadapi di dunia kerja sehingga membingungkan lulusan akuntansi karena pemahaman yang berbeda. Fred et al. (2012) mengemukakan tanda seorang mahasiswa memahami akuntansi tidak hanya ditunjukkan dari nilai-nilai yang didapatkannya dalam mata kuliah tetapi juga apabila mahasiswa tersebut mengerti dan dapat menguasai konsep-konsep yang terkait. Berdasarkan definisi diatas, maka dapat disimpulkan bahwa pemahaman akuntansi adalah proses atau cara mahasiswa jurusan akuntansi dalam memahami mata kuliah akuntansi. Ada beberapa faktor-faktor yang dapat mempengaruhi tingkat pemahaman akuntansi yaitu kecerdasan emosional, kecerdasan spiritual, kecerdasan intelektual, perilaku belajar, budaya, ketrampilan sosial, kepercayaan diri, dan minat membaca.

Salah satu faktor yang dapat memengaruhi tingkat pemahaman akuntansi adalah kecerdasan emosional. Menurut Cetin (2016) bahwa kecerdasan emosional adalah kemampuan lebih yang dimiliki oleh seseorang dalam memotivasi diri, ketegaran dalam menghadapi kegagalan, mampu mengendalikan emosi dan menunda kepuasan, serta mengatur keadaan jiwa. Brackett et al. (2011) mengemukakan kecerdasan emosional adalah keseluruhan kemampuan yang memengaruhi bagaimana individu memanfaatkan emosi untuk memfasilitasi pemikiran atau mengatur emosi untuk fokus pada informasi yang penting. Kecerdasan emosional yang baik dapat dilihat dari kemampuan mengenal diri sendiri, mengendalikan diri, memotivasi diri, berempati, dan kemampuan sosial 
Ida Ayu Clara Agustin dan I Ketut Sujana. Pengaruh...

(Abraham, 2010). Mahasiswa yang memiliki kecerdasan emosional akan menjadi "nilai plus" dalam menghadapi permasalahan yang dihadapinya. Karena kecerdasan emosional tidak hanya menentukan seberapa besar tingkat kesabaran dari mahasiswa, namun lebih dari itu kecerdasan emosional juga memengaruhi motivasi dan semangat belajar.

Penelitian terdahulu yang dilakukan oleh Ariantini (2017), Fanikmah (2016), dan Khajehpour (2011) memperoleh hasil bahwa kecerdasan emosional berpengaruh positif terhadap pemahaman akuntansi. Namun hasil berbeda ditemukan dalam penelitian yang dilakukan oleh Trisnawati dan Suryaningrum (2003), Hakim (2010), Laksmi dan Sujana (2017) bahwa kecerdasan emosional berpengaruh negatif terhadap tingkat pemahaman akuntansi. Selain kecerdasan emosional, kecerdasan spritual juga dapat mempengaruhi bagaimana tingkat pemahaman akuntansi seseorang.

Zohar dan Marshall (2001) mengemukakan bahwa kecerdasan spiritual adalah kecerdasan untuk menghadapi dan memecahkan persoalan makna dan nilai, yaitu menempatkan perilaku dan hidup manusia dalam konteks makna yang lebih luas dan kaya, serta menilai bahwa tindakan atau hidup seseorang lebih bermakna dibandingkan dengan yang lain. Khavari (2000) mendefinisikan kecerdasan spiritual sebagai dimensi nonmaterial ataujiwa manusia. Kecerdasan spiritual diumpamakan sebagai intan yang belum terasah dan manusia harus mengenali seperti adanya lalu menggosoknya sehingga mengkilap dengan tekad yang besar, menggunakannya menuju kearifan, dan untuk mencapai kebahagiaan yang abadi. Kecerdasan spiritual merupakan landasan yang diperlukan untuk 
memfungsikan kecerdasan intelektual dan kecerdasan emosional secara efektif. Kecerdasan spiritual dan kecerdasan emosional memiliki keterkaitan, yaitu kecerdasan spiritual mengatur emosi seseorang dalam menanggapi masalah yang sedang dihadapi (Ronnel, 2008). Kecerdasan spiritual yang baik dapat dilihat dariketuhanan, kepercayaan, kepemimpinan pembelajaran, berorientasi masa depan, dan keteraturan. Oleh karena itu, mahasiswa yang memiliki kecerdasan spiritual yang tinggi akan memotivasi dirinya untuk lebih giat belajar karena mahasiswa yang memiliki kecerdasan spiritual yang tinggi, memiliki rasa ingin tahu yang tinggi, sehingga memiliki motivasi untuk selalu belajar dan memiliki kreativitas yang tinggi pula. Begitu pula sebaliknya, mahasiswa dengan kecerdasan spiritual yang rendah akan kurang termotivasi dalam belajar yang terjadi adalah melakukan segala cara untuk mendapatkan nilai yang baik, sehingga pemahaman dalam akuntansi menjadi kurang.

Penelitian yang dilakukan oleh Sahara (2014), Juliastantri (2014), Laksmi dan Sujana (2017), serta Clarken (2010), memperoleh hasil kecerdasan spiritual berpengaruh positif terhadap pemahaman akuntansi. Selain itu Junifar (2015) juga meneliti pengaruh kecerdasan spiritual pada tingkat pemahaman akuntansi mahasiswa S1 Sekolah Tinggi Ilmu Ekonomi Indonesia angkatan 2011dan memperoleh hasil bahwa kecerdasan spiritual berpengaruh positif terhadap pemahaman akuntansi. Namun penelitian lain yang dilakukan oleh Artana (2014) menemukan bahwa kecerdasan spiritual berpengaruh negatif terhadap pemahaman akuntansi.Seseorang yang hanya mengandalkan kecerdasan intelektual tanpa menyeimbangkan sisi spiritual akan menghasilkan individu yang mudah putus 
Ida Ayu Clara Agustin dan I Ketut Sujana. Pengaruh...

asa, depresi, suka tawuran bahkan menggunakan obat-obat terlarang.Kurangnya kecerdasan spiritual dalam diri seorang mahasiswa akan mengakibatkan mahasiswa kurang termotivasi untuk belajar dan sulit untuk berkonsentrasi sehingga akan berpengaruh terhadap perilaku belajarnya yang menjadikan mahasiswa akan sulit untuk memahami suatu mata kuliah.

Perilaku belajar juga dapat memengaruhi mahasiswa pada tingkat pemahaman akuntansi. Perilaku belajar mahasiswa yang terdiri dari kebiasaan mengikuti pelajaran, kebiasaaan membaca buku, kunjungan ke perpustakaan, dan kebiasaan menghadapi ujian akan sangat penting peranannya (Lunenburg, 2011). Menurut Smith (2001) belajar yang efisien dapat dicapai apabila menggunakan strategi yang tepat, yakni adanya pengaturan waktu yang baik dalam mengikuti perkuliahan, belajar di rumah, berkelompok ataupun untuk mengikuti ujian. Semakin baik perilaku belajar seorang mahasiswa maka akan semakin baik pula tingkat pemahaman akuntansinya.

Hasil penelitian Artana (2014), dan Dewi (2016) menyatakan perilaku belajar berpengaruh positif terhadap tingkat pemahaman akuntansi. Namun hasil penelitian Sahara (2014) dan Dwi et al. (2014) bahwa perilaku belajar tidak berpengaruh terhadap tingkat pemahaman akuntansi.

Tingkat pemahaman akuntansiyang baik nantinya akan melahirkan caloncalon akuntan yang profesional dibidangnya. Pengetahuan yang dibutuhkan oleh akuntan terdiri dari pengetahuan umum, organisasi, bisnis, dan akuntansi (Haryoga dan Supriyanto, 2011). Menurut Pedoman Akademik (2016), mata kuliah akuntansi yang diajarkan di Fakultas Ekonomi dan Bisnis Universitas 
Udayana dibagi menjadi 2 bagian, yaitu mata kuliah inti dan mata kuliah pilihan. Mata kuliah inti adalah mata kuliah yang wajib ditempuh oleh mahasiswa akuntansi seperti, pengantar akuntansi, akuntansi keuangan, akuntansi biaya, akuntansi sektor publik, akuntansi manajemen, akuntansi keuangan lanjutan, sistem informasi akuntansi, akuntansi perbankan dan LPD, teori akuntansi, akuntansi hotel, aplikasi komputer akuntansi, dan seminar akuntansi. Mata kuliah pilihan adalah mata kuliah yang dapat dipilih oleh mahasiswa sesuai dengan minatnya. Mata kuliah pilihan terdiri dari 2 pilihan yaitu 1) Mata Kuliah Keahlian Berkarya (MKB) seperti, akuntansi pemerintahan Indonesia, perilaku keorganisasian, analisis informasi keuangan, akuntansi internasional, dan sistem pengendalian manajemen. 2) Mata Kuliah Perilaku Berkarya (MPB) seperti, akuntansi keperilakuan, kepemimpinan dalam bisnis, manajemen inovasi dan kreativitas, perencanaan dan simulasi bisnis, motivasi bisnis, corporate governance (CG). Dalam penelitian ini mata kuliah yang dijadikan dasar kuesioner adalah pengantar akuntansi II, akuntansi sektor publik, akuntansi manajemen, akuntansi perbankan dan LPD, aplikasi komputer akuntansi, akuntansi hotel, dan seminar akuntansi. Mata kuliah tersebut merupakan mata kuliah akuntansi akhir yang harus ditempuh dan sudah memenuhi syarat-syarat mata kuliah dasar, seperti pengantar akuntansi I, akuntansi biaya, akuntansi keuangan, sistem informasi akuntansi, dan teori akuntansi. Mata kuliah yang dipilih sebagai kriteria pemahaman akuntansi dalam penelitian ini berdasarkan pohon kurikulum jurusan akuntansi Fakultas Ekonomi dan Bisnis Universitas Udayana. 
Ida Ayu Clara Agustin dan I Ketut Sujana. Pengaruh...

Fenomena yang terjadi dalam penelitian ini adalah masih banyak terdapat mahasiswa yang kurang paham terhadap mata kuliah akuntansi yang ditandai oleh diperolehnya nilai $\mathrm{C}+$ hingga $\mathrm{E}$ pada mata kuliah akuntansi khususnya pada mahasiswa nonreguler, seperti pada Tabel berikut:

Tabel 1.

Data Nilai Mahasiswa Reguler dan Nonreguler Jurusan Akuntansi Angkatan 2014 Tahun Ajaran 2017/2018

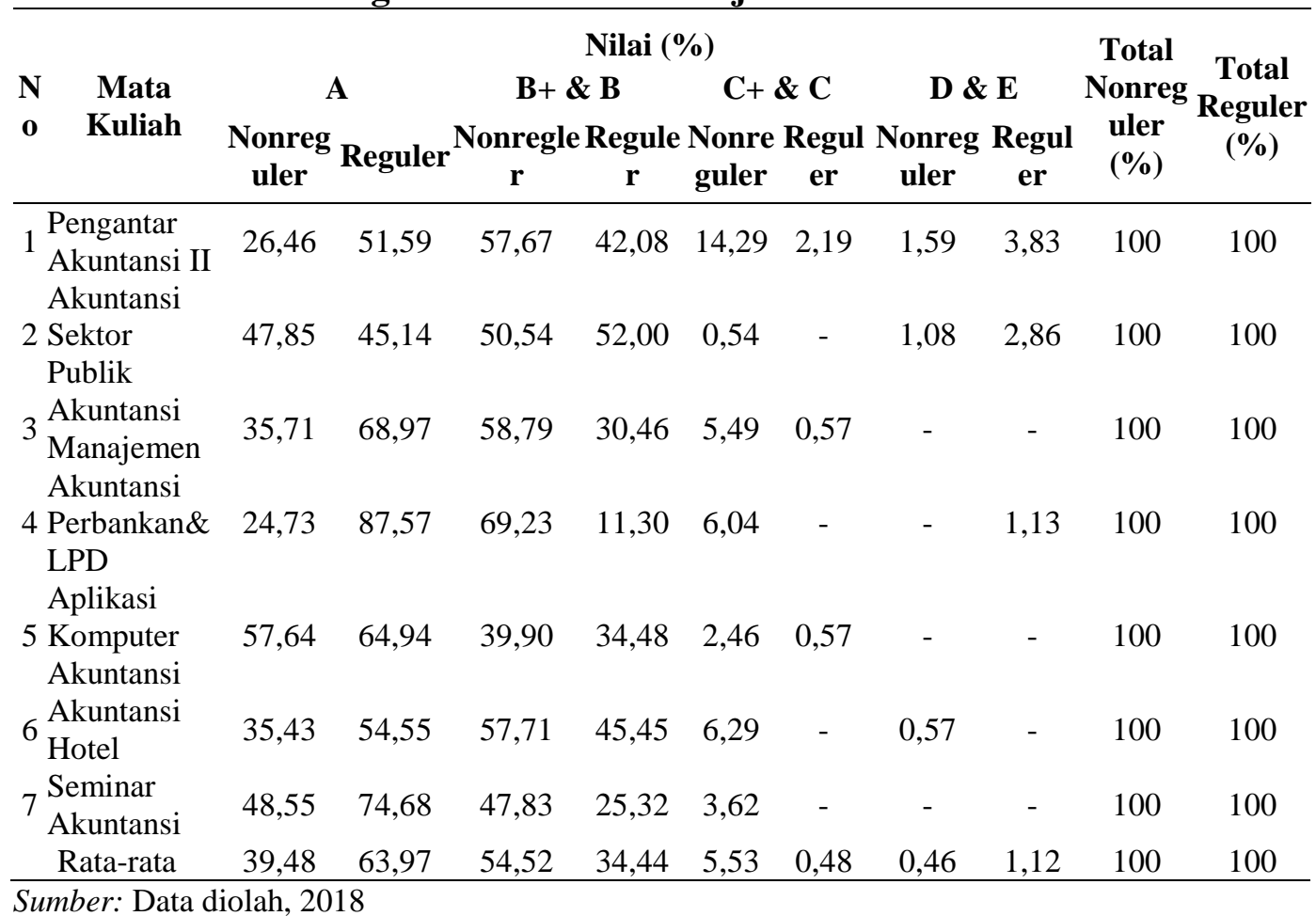

Pada Tabel 1 di atas dapat diketahui mahasiswa nonreguler jurusan akuntansiangkatan 2014 memiliki rata-rata nilai $\mathrm{C}+$ hingga E yang lebih tinggi dibandingkan mahasiswa reguler jurusan akuntansi angkatan 2014 yaitu untuk mahasiswa nonreguler sebesar 5,99\% dan mahasiswa regular hanya sebesar 1,60\%. Hal tersebut mungkin dikarenakanmahasiswa terbiasa dengan pola belajar menghafal tetapi tidak memahami materi yang diberikan, sehingga mahasiswa cenderung mudah lupa dengan apa yang dipelajari atau kesulitan untuk 
memahami materi yang diajarkan, sehingga menjadi salah satu penyebab kurangnya tingkat pemahaman akuntansi pada mahasiswa.

Responden yang dipilih dalam penelitian ini adalah mahasiswa nonregulerjurusan akuntansi program S1 Fakultas Ekonomi dan Bisnis Universitas Udayana angkatan 2014. Responden mahasiswa akuntansi dipilih karena mahasiswa nonreguler jurusan akuntansi program S1 angkatan 2014 kini (pada saat penelitian) telah berada di akhir masa perkuliahan sehingga diharapkan telah memiliki gambaran mengenai manfaat maksimal dari proses belajar akuntansi. Selain itu, berdasarkan tabel 1 diperoleh hasil bahwa nilai mata kuliah akuntansi mahasiswa nonreguler lebih rendah dan lebih banyak memperoleh nilai $\mathrm{C}+$ hingga $\mathrm{E}$ daripada nilai mata kuliah akuntansi mahasiswa reguler. Alasan lainnya adalah mahasiswa non reguler jurusan akuntansi sebagian besar kuliah sambil bekerja.

Kecerdasan emosional dalam diri seseorang mampu untuk mengetahui dan menanggapi perasaan mereka sendiri dengan baik dan mampu membaca dan menghadapi perasaan orang lain dengan efektif. Goleman (2011) mengemukakan bahwa kecerdasan emosional memiliki peran besar dalam mencapai kesuksesan kehidupan pribadi maupun profesional. Untuk menjadi seorang lulusan akuntansi yang berkualitas, diperlukan waktu yang panjang dan usaha yang keras serta dukungan dari pihak lain yang akan memengaruhi pengalaman hidup lulusan tersebut. Kecerdasan emosional ditandai oleh kemampuan pengenalan diri, pengendalian diri, motivasi diri, empati, dan kemampuan sosial yang akan memengaruhi perilaku belajar mahasiswa yang nantinya juga memengaruhi 
Ida Ayu Clara Agustin dan I Ketut Sujana. Pengaruh...

seberapa besar mahasiswa dalam memahami mata kuliah akuntansi.Semakin tinggi tingkat kecerdasan emosional mahasiswa, maka akan semakin tinggi pula tingkat pemahaman akuntansinya. Kecerdasan emosional juga yang mendukung mahasiswa dalam mencapai tujuan dan cita-citanya.

Penelitian yang dilakukan oleh Artana (2014) menyatakan bahwa kecerdasan emosional berpengaruh positif terhadap pemahaman mahasiswa S1 akuntansi di Universitas Pendidikan Ganesha Singaraja dan Universitas Udayana Denpasar. Penelitian lain olehJunifar (2015), Triarina dan Rony (2015), Rusmiani (2017), Dewi dan Wirama (2016), serta Ariantini (2017) juga menunjukkan hasil yang sama yaitu kecerdasan emosional memiliki pengaruh positif terhadap tingkat pemahaman akuntansi. Berdasarkan uraian di atas, maka dapat dibuat hipotesis yaitu:

$\mathrm{H}_{1}$ : Kecerdasan emosional berpengaruh positif pada tingkatpemahaman akuntansi

Kecerdasan spiritual adalah landasan yang diperlukan untuk memfungsikan kecerdasan intelektual dan kecerdasan emosional secara efektif.Sistem pembelajaran yang hanya terpusat pada kecerdasan intelektual tanpa menyeimbangkan dengan kecerdasan spiritual dapat menghasilkan sumber daya manusia yang mudah putus asa dan mudah depresi, sehingga mahasiswa sering melupakan tugasnya sebagai mahasiswa yaitu belajar. Kurangnya kecerdasan spiritual pada diri mahasiswa akan mengakibatkan mahasiswa kurang termotivasi untuk belajar dan sulit berkonsentrasi, sehingga membuat mahasiswa sulit untuk memahami mata kuliah khususnya mata kuliah akuntansi. Mahasiswa yang hanya mengejar prestasi berupa nilai IPK yang tinggi dan mengabaikan nilai spiritual, 
mereka akan menggunakan segala cara agar memperoleh nilai yang bagus atau tinggi walaupun dengan cara yang tidak jujur seperti menyontek pada saat ujian.

Penelitian yang dilakukan Juliastantri (2014) memperoleh hasil kecerdasan spiritual berpengaruh positif terhadap tingkat pemahaman akuntansi. Hasil serupa juga ditemukan oleh Junifar (2015) kecerdasan spiritual berpengaruh positif pada tingkat pemahaman akuntansi mahasiswa S1 Sekolah Tinggi Ilmu Ekonomi Indonesia angkatan 2011. Penelitian lain oleh Triarina dan Boy (2015), Clarken (2010), dan Sahara (2014) memperoleh hasil kecerdasan spiritual berpengaruh secara signifikan terhadap pemahaman akuntansi. Berdasarkan uraian di atas, maka dapat dibuat hipotesis yaitu:

$\mathrm{H}_{2}$ : Kecerdasan spiritual berpengaruh positif pada tingkat pemahaman akuntansi

Hanifah dan Syukriy (2001) dalam Junifar (2015) mengemukakan belajar yang efisien dapat dicapai apabila menggunakan strategi yang tepat, yaitu pengelolaan waktu yang baik dalam mengikuti perkuliahan, belajar di rumah, berkelompok, ataupun untuk mengikuti ujian. Perilaku belajar yang baik dapat terwujud mahasiswa sadar akan kewajibannya sebagai mahasiswa dan mulai mengatur waktu dengan baik antara belajar dan kegiatan lainnya.Perilaku belajar yang baik akan mengarah pada pemahaman terhadap pelajaran akuntansi menjadi maksimal, sedangkan perilaku belajar yang buruk akan mengarah pada pemahaman terhadap pelajaran akuntansi menjadi kurang maksimal. Pengukuran prestasi akademik merupakan hal yang penting untuk mengetahui tingkat keberhasilan mahasiswa dalam belajar. Jadi jika mahasiswa telah melalui serangkaian proses belajar yang ditempuhnya dengan baik, maka prestasi 
Ida Ayu Clara Agustin dan I Ketut Sujana. Pengaruh...

akademik mahasiswa akan semakin baik. Hal-hal yang berhubungan dengan perilaku belajar yang baik dilihat dari kebiasaan mengikuti pelajaran, kebiasaan membaca buku, kunjungan ke perpustakaan, dan kebiasaan menghadapi ujian (Marita dan Naafi, 2010).

Penelitian Junifar (2015) menyimpulkan bahwa perilaku belajar berpengaruh positif terhadap pemahaman akuntansi. Penelitian lain yang memperoleh hasil serupa adalah penelitian yang dilakukan oleh Artana (2014), Agustina dan Yanti (2015), Rusmiani (2017), Dewi dan Wirama (2016) bahwa perilaku belajar berpengaruh positif terhadap pemahaman akuntansi. Berdasarkan uraian di atas, maka dapat dibuat hipotesis yaitu:

$\mathrm{H}_{3}$ : Perilaku belajar berpengaruh positif pada tingkat pemahaman akuntansi

\section{METODE PENELITIAN}

Penelitian ini menggunakan pendekatan kuantitatif dengan tingkat eksplanasi penelitian berbentuk asosiatif. Berikut desain penelitian dalam penelitian ini :

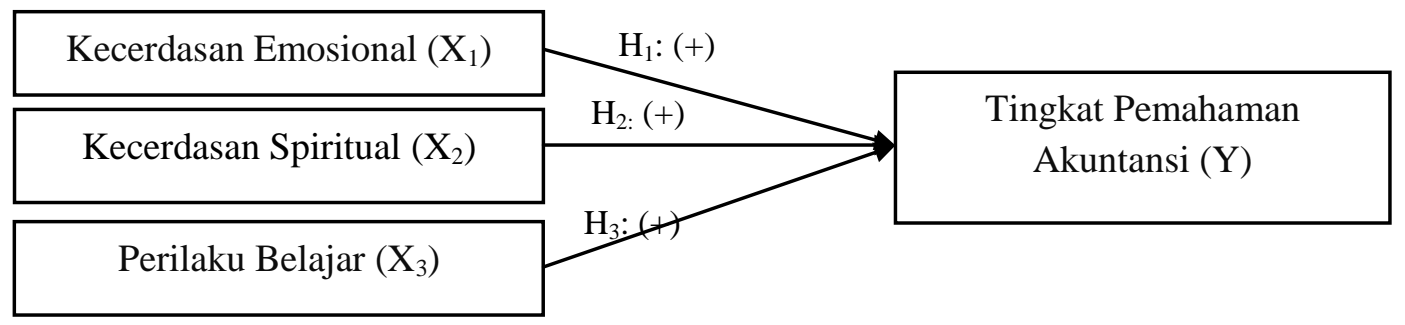

Gambar 1. Desain Penelitian

Lokasi penelitian dilakukan di Fakultas Ekonomi dan Bisnis Universitas Udayana dengan menyebarkan kuesioner kepada mahasiswa S1 nonreguler jurusan akuntansi angkatan 2014. Objek dari penelitian ini adalah kecerdasan emosional, kecerdasan spiritual, perilaku belajar, dan tingkat pemahaman 
akuntansi mahasiswa S1 nonreguler jurusan akuntansi angkatan 2014 di Fakultas Ekonomi dan Bisnis Universitas Udayana.

Variabel terikat dalam penelitian ini adalah tingkat pemahaman akuntansi (Y). Sedangkan variabel bebas dalam penelitian ini adalah kecerdasan emosional $\left(\mathrm{X}_{1}\right)$, kecerdasan spiritual $\left(\mathrm{X}_{2}\right)$, dan perilaku belajar $\left(\mathrm{X}_{3}\right)$.

Populasi dalam penelitian ini adalah seluruh mahasiswa nonreguler jurusan akuntansi yang berjumlah 186 mahasiswa dan mahasiswa aktif sebanyak 186 mahasiswa program S1 angkatan 2014 Fakultas Ekonomi dan Bisnis Universitas Udayana. Metode penentuan sampel dalam penelitian ini menggunakan metode purposive sampling. Penentuan jumlah sampel menggunakan rumus Slovin yaitu sebagai berikut (Junifar, 2015):

$\mathrm{n}=\frac{\mathrm{N}}{1+\mathrm{N} \cdot \mathrm{e}^{2}}$

Keterangan:

$\mathrm{N} \quad=$ Ukuran populasi

$\mathrm{n} \quad=$ Ukuran sampel

e $\quad=$ Presisi $($ prosentase kesalahan $=5 \%)$

maka dengan perhitungan responden sebagai berikut:

$\mathrm{n}=\frac{186}{1+186 \cdot(0,05)^{2}}$

$\mathrm{n}=126,96$

Dari perhitungan diatas, maka penulis dapat menetapkan besarnya sampel dari populasi yaitu 126 mahasiswa (dibulatkan).

Jenis data yang digunakan dalam penelitian ini adalah data kualitatif berupa daftar pernyataan - pernyataan yang terdapat dalam kuesioner. Data kuantitatif berupa data skor jawaban kuesioner yang terkumpul dan jumlah mahasiswa non 
Ida Ayu Clara Agustin dan I Ketut Sujana. Pengaruh...

reguler jurusan akuntansi angkatan 2014 di Fakultas Ekonomi dan Bisnis Universitas Udayana. Sedangkan sumber data yang digunakan dalam penelitian ini adalah data primer berupa kuesioner yang telah diisi oleh mahasiswa nonreguler jurusan akuntansi Fakultas Ekonomi dan Bisnis Universitas Udayana yang telah menjadi responden pada penelitian ini. Data sekunder berupa bukti, catatan atau laporan historis yang telah tersusun dalam arsip yang dipublikasikan atau tidak dipublikasikan yang diperoleh dengan menggunakan metode tinjauan kepustakaan dan mengakses website maupun situs-situs.

Metode pengumpulan data yang digunakan dalam penelitian ini adalah survey dengan menyebarkan kuesioner kepada responden. Kuesioner langsung diantarkan ke lokasi penelitian dan diberikan kepada responden. Jenis kuesioner yang digunakan adalah kuesioner tertutup. Hasil kuesioner diukur menggunakan skala likert modifikasi 4 poin dari sangat tidak setuju (1), tidak setuju (2), setuju (3), sangat setuju (4). Tujuan penggunaan skala likert modifikasi 4 poin adalah untuk menghindari hasil yang bias dari kuesioner yang telah disebar.

Teknik analisis data yang digunakan dalam penelitian ini adalah teknik analisis regresi linier berganda. Sebelum melakukan pengujian regresi, terdapat beberapa asumsi yang harus dipenuhi agar data yang akan dimasukkan dalam model regresi telahmemenuhi ketentuan dan syarat dalam regresi. Uji asumsi klasik dalam penelitianini mencakup uji normalitas, multikolinearitas, dan heteroskedastisitas. Model regresi linier berganda dirumuskan sebagai berikut.

$\mathrm{Y}=\alpha+\beta_{1} \mathrm{X}_{1}+\beta_{2} \mathrm{X}_{2}+\beta_{3} \mathrm{X}_{3}+\varepsilon$ 
Keterangan :

Y : Tingkat Pemahaman Akuntansi

$\alpha \quad$ : Nilai konstanta

$\beta_{1,}, \beta_{2}, \beta_{3}:$ Koefisien regresi

$\mathrm{X}_{1} \quad$ : Kecerdasan Emosional

$\mathrm{X}_{2} \quad$ :Kecerdasan Spiritual

$\mathrm{X}_{3} \quad$ : Perilaku Belajar

$\varepsilon \quad$ : error term (komponen pengganggu)

\section{HASIL DAN PEMBAHASAN}

Dalam penelitian ini karakteristik responden merupakan profil dari 126 responden yang berpartisipasi dalam pengisian kuesioner penelitian ini. Profil responden memaparkan mengenai karakteristik responden penelitian mahasiswa nonreguler jurusan akuntansi angkatan 2014 Fakultas Ekonomi dan Bisnis Universitas Udayana berdasarkan jenis kelamin.

Tabel 2.

Karakteristik Responden Penelitian Mahasiswa nonreguler jurusan akuntansi angkatan 2014 Fakultas Ekonomi dan Bisnis Universitas Udayana Berdasarkan Jenis Kelamin

\begin{tabular}{cccc}
\hline Karakteristik & Kategori & Frekuensi & Persentase \\
\hline \multirow{2}{*}{ Jenis Kelamin } & Perempuan & 95 & 75,4 \\
& Laki-laki & 31 & 24,6 \\
& Total & 126 & 100.0 \\
\hline
\end{tabular}

Sumber: Data diolah, 2018

Berdasarkan Tabel 2. menunjukkan bahwa sebagian besar responden adalah perempuan dengan persentase sebesar 75,4 persen, sedangkan hanya 24,6 persen merupakan responden laki-laki.

Analisis statistik deskriptif digunakan untuk memberi gambaran atau penjelasan suatu data pada variabel penelitian. 
Ida Ayu Clara Agustin dan I Ketut Sujana. Pengaruh...

Tabel 3.

Hasil Analisis Statistik Deskriptif

\begin{tabular}{lccccc}
\hline & $\mathbf{N}$ & Minimum & Maximum & Mean & Std. Deviation \\
\hline Pemahaman & 126 & 12.00 & 28.00 & 23.1111 & 2.52102 \\
Emosional & 126 & 45.00 & 81.00 & 66.6032 & 7.63474 \\
Spiritual & 126 & 43.00 & 72.00 & 58.0556 & 5.38339 \\
Perilaku & 126 & 23.00 & 50.00 & 39.6746 & 5.65520 \\
\hline
\end{tabular}

Sumber: Data diolah, 2018

Berdasarkan Tabel 3. dapat dilihat bahwa jumlah pengamatan $(\mathrm{N})$ pada penelitian ini adalah sebanyak 126 . Variabel kecerdasan emosional $\left(\mathrm{X}_{1}\right)$ memiliki nilai rata-rata sebesar 66,60 mendekati nilai maksimum sebesar 81,00 , berarti kecerdasan emosional pada mahasiswa nonreguler cukup tinggi. Standar deviasi sebesar 7,63 lebih kecil dari nilai rata-rata, artinya ada fluktuasi yang rendah pada kecerdasan emosional mahasiswa yang menjadi sampel. Variabel kecerdasan spiritual $\left(\mathrm{X}_{2}\right)$ memiliki nilai rata-rata sebesar 58,05 mendekati nilai maksimum sebesar 72,00, berarti kecerdasan spiritual pada mahasiswa non reguler cukup tinggi. Standar devisiasi sebesar 5,38 lebih kecil dari nilai rata-rata artinya ada fluktuasi yang rendah pada kecerdasan spiritual mahasiswa yang menjadi sampel. Variabel perilaku belajar $\left(\mathrm{X}_{3}\right)$ memiliki nilai rata-rata sebesar 39,67 mendekati nilai maksimum sebesar 50,00, berarti perilaku belajar pada mahasiswa non reguler cukup tinggi. Standar devisiasi sebesar 5,65 lebih kecil dari nilai rata-rata artinya ada fluktuasi yg rendah pada perilaku belajar mahasiswa yang menjadi sampel. Variabel tingkat pemahaman akuntansi (Y) memiliki nilai rata-rata sebesar 23,11 mendekati nilai maksimum sebesar 28,00, berarti pemahaman akuntansi pada mahasiswa non reguler cukup tinggi. Standar devisiasi sebesar 2,52 lebih kecil dari nilai rata-rata artinya ada fluktuasi yang rendah pada pemahaman mahasiswa yang menjadi sampel. 
Suatu instrumen yang valid ditunjukkan dengan $\mathrm{r}$ Pearson Correlation $\geq$ 0,30. Pada hasil perhitungan menunjukkan bahwa seluruh variabel memiliki nilai koefisien korelasi dengan skor total seluruh item pernyataan lebih besar dari 0,30. Hal ini menunjukkan butir-butir pernyataan dalam instrumen penelitian tersebut valid. Indikator/pertanyaan yang digunakan layak digunakan untuk mengukur apa yang seharusnya diukur, dan dapat mengungkap data dari variabel yang diteliti secara tepat.

Uji reliabilitas mampu menunjukan sejauh mana instrument dapat dipercaya dan diharapkan. Nilai suatu instrument dikatakan reliable apabila nilai Alpha Cronbach $\geq 0,60$. Hasil uji reliabilitas dapat dilihat pada Tabel 4.

Tabel 4.

Hasil Uji Reliabilitas Variabel Kecerdasan Emosional, Kecerdasan Spiritualdan Tingkat Pemahaman Akuntansi

\begin{tabular}{clcc}
\hline No. & \multicolumn{1}{c}{ Variabel } & Cronbach's Alpha & Keterangan \\
\hline 1 & Kecerdasan Emosional $\left(\mathrm{X}_{1}\right)$ & 0,924 & Reliabel \\
2 & Kecerdasan Spiritual $\left(\mathrm{X}_{2}\right)$ & 0,855 & Reliabel \\
3 & Perilaku Belajar $\left(\mathrm{X}_{3}\right)$ & 0,869 & Reliabel \\
4 & Tingkat Pemahaman Akuntansi $(\mathrm{Y})$ & 0,625 & Reliabel \\
\hline Sumber: & Data diolah, 2018
\end{tabular}

Berdasarkan Tabel 4. dapat dilihat bahwa nilai alpha di hitung masingmasing variabel lebih besar dari $\mathrm{R}$ alpha tabel yaitu 0,60 sehingga dapat disimpulkan bahwa pernyataan dalam kuesioner tersebut reliabel.

Uji normalitas menggunakan uji Kolmogorov-Smirnov, dengan uji ini dapat diketahui data yang digunakan berdistribusi normal atau tidak. Apabila Sign t hitung $>0.05$, maka data tersebut berdistribusi normal dan begitu juga sebaliknya (Santoso, 2001). 
Tabel 5.

Hasil Uji Normalitas

\begin{tabular}{lc}
\hline & Unstandardized Residual \\
\hline $\mathrm{N}$ & 126 \\
Kolmogorov-Smirnov $\mathrm{Z}$ & 1,237 \\
Asymp.Sig.(2-tailed) & 0,094 \\
\hline Sumber: Data diolah, 2018 &
\end{tabular}

Berdasarkan Tabel 5. dapat dilihat bahwa nilai Kolmogorov Sminarnov (KS) sebesar 1,237, sedangkan nilai Asymp.Sig. (2-tailed) sebesar 0,094. Hasil tersebut mengindikasikan bahwa model persamaan regresi tersebut berdistribusi normal karena nilai Asymp. Sig. (2-tailed) 0,094 lebih besar dari nilai alpha 0,05.

Uji multikolinieritas digunakan untuk mengetahui apakah antara variabel bebas terjadi multikolinieritas atau tidak. Uji yang digunakan yaitu dengan melihat nilai VIF (Varian Inflation Factor) dan Tolerance pada proses regresi biasa, jika keduanya mendekati 1 atau besaran VIF kurang dari 10 maka model tidak terkena multikolinieritas.

Tabel 6.

Hasil Uji Multikolinearitas

\begin{tabular}{lcc}
\hline \multicolumn{1}{c}{ Variabel } & Tolerance & VIF \\
\hline Kecerdasan Emosional $\left(\mathrm{X}_{1}\right)$ & 0,332 & 3,009 \\
Kecerdasan Spiritual $\left(\mathrm{X}_{2}\right)$ & 0,459 & 2,179 \\
Perilaku Belajar $\left(\mathrm{X}_{3}\right)$ & 0,435 & 2,298 \\
\hline Sumber: Data diolah, 2018 & &
\end{tabular}

Berdasarkan Tabel 6. dapat dilihat bahwa nilai tolerance dan VIF dari variabel kecerdasan emosional, kecerdasan spiritual, dan perilaku belajar. Nilai tersebut menunjukkan bahwa nilai tolerance untuk setiap variabel lebih besar dari 0,1 dan nilai VIF lebih kecil dari 10 yang berarti model persamaan regresi bebas dari multikolinearitas. 
Uji Heteroskedastisitas bertujuan untuk menguji apakah dalam model terjadi ketidaksamaan varian atau residual satu pengamatan ke pengamatan lainnya. Jika tingkat signifikan lebih besar dari 0,05 maka terjadi heteroskedastisitas.

Pada Tabel 7. dapat dilihat bahwa nilai Sig. dari masing-masing variabel adalah sebesar 0,476, 0,168 dan 0,480. Nilai tersebut lebih besar dari 0,05 yang berarti tidak terdapat pengaruh antara variabel bebas terhadap absolute residual. Dengan demikian, model yang dibuat tidak mengandung gejala heteroskedastisitas.

Tabel 7.

Hasil Uji Heteroskedastisitas

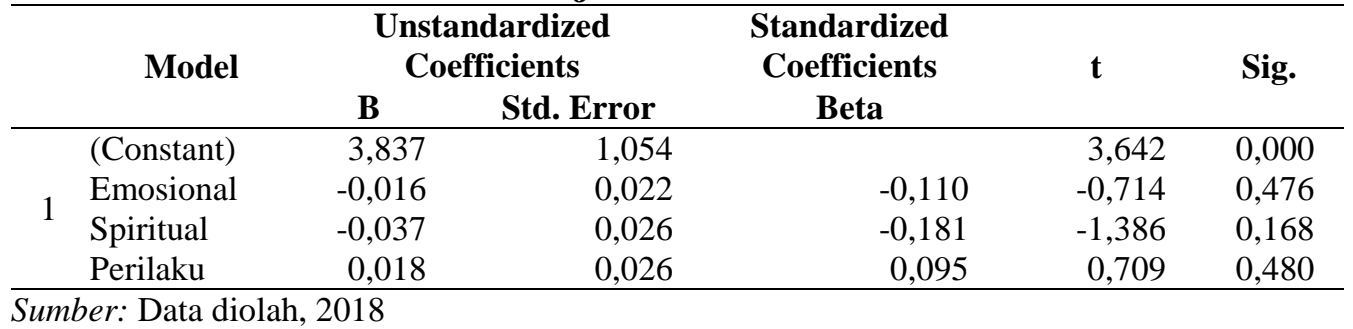

Sesuai dengan hasil perhitungan dengan menggunakan program SPSS for windows maka diperoleh hasil analisis regresi linear berganda.

Tabel 8.

Hasil Analisis Regresi Linear Berganda

\begin{tabular}{|c|c|c|c|c|c|c|c|}
\hline & \multirow[t]{2}{*}{ Model } & & \multicolumn{2}{|c|}{$\begin{array}{l}\text { Unstandardized } \\
\text { Coefficients }\end{array}$} & \multirow{2}{*}{$\begin{array}{c}\text { Standardized } \\
\text { Coefficients } \\
\text { Beta }\end{array}$} & \multirow[t]{2}{*}{$\mathbf{t}$} & \multirow[t]{2}{*}{ Sig. } \\
\hline & & & B & Std. Error & & & \\
\hline \multirow{4}{*}{1} & (Constant) & & 6,149 & 1,751 & & 3,511 & 0,001 \\
\hline & Emosional & & 0,085 & 0,036 & 0,257 & 2,330 & 0,021 \\
\hline & Spiritual & & 0,090 & 0,044 & 0,193 & 2,052 & 0,042 \\
\hline & Perilaku & & 0,153 & 0,043 & 0,343 & 3,550 & 0,001 \\
\hline \multicolumn{2}{|c|}{ F hitung } & $: 41,573$ & & & & & \\
\hline \multicolumn{2}{|c|}{ Sig. F } & $: 0,000$ & & & & & \\
\hline \multicolumn{2}{|c|}{$\mathrm{R}^{2}$} & $: 0,506$ & & & & & \\
\hline \multicolumn{2}{|c|}{ Adj. $\mathrm{R}^{2}$} & $: 0,493$ & & & & & \\
\hline
\end{tabular}

Berdasarkan hasil analisis regresi linier berganda seperti yang disajikan pada Tabel 8. maka persamaan strukturalnya adalah sebagai berikut: 
Ida Ayu Clara Agustin dan I Ketut Sujana. Pengaruh...

$$
\mathrm{Y}=6,149+0,085 \mathrm{X} 1+0,090 \mathrm{X} 2+0,153 \mathrm{X} 3
$$

Persamaan di atas menunjukkan bahwa konstanta sebesar 6,149 memiliki arti apabila kecerdasan emosional, kecerdasan spiritual, dan perilaku belajar sama dengan nol, maka tingkat pemahaman akuntansi sebesar 6,149. Kecerdasan emosional sebesar 0,085 mempunyai arti bahwa apabila kecerdasan emosional naik 1 satuan maka menyebabkan tingkat pemahaman akuntansi naik sebesar 0,085 satuan dengan asumsi variabel lainnya konstan. Kecerdasan spiritual sebesar 0,090, mempunyai arti bahwa apabila kecerdasan emosional naik 1 satuan maka menyebabkan tingkat pemahaman akuntansi naik sebesar 0,090 satuan dengan asumsi variabel lainnya konstan. Perilaku belajar sebesar 0,153 mempunyai arti bahwa apabila perilaku belajar naik 1 satuan maka menyebabkan tingkat pemahaman akuntansi naik sebesar 0,153 satuan dengan asumsi variabel lainnya konstan.

Berdasarkan Tabel 8. menunjukkan bahwa koefisien determinasi yaitu nilai adjusted $R^{2}$ adalah 0,493 mempunyai arti bahwa sebesar 49,3\% variasi tingkat pemahaman akuntansidipengaruhi oleh variasi kecerdasan emosional, kecerdasan spiritual, dan perilaku belajar, sedangkan sisanya sebesar 50,7\% djelaskan oleh faktor lain yang tidak dimasukkan ke dalam model.

Uji kelayakan model bertujuan untuk mengetahui apakah model regresi yang digunakan dalam penelitian ini layak atau tidak digunakan sebagai alat analisis untuk menguji pengaruh variabel bebas pada variabel terikatnya. Hasil uji anova (Uji F), diperoleh nilai $F$ hitung sebesar 41,573 dengan nilai sig. 0,000 
yang lebih kecil dari 0,05 . Maka Ho ditolak pada taraf nyata $0,05\left(\mathrm{H}_{1}\right.$ diterima). Kesimpulannya, model yang diestimasi layak digunakan untuk menjelaskan pengaruh variabel-variabel bebas terhadap variabel terikat.

Uji hipotesis bertujuan untuk mengetahui apakah masing-masing variabel independen mempunyai pengaruh secara signifikan pada variabel dependennya. Level of significant yang digunakan adalah 0,05 (5\%). Apabila probabilitas signifikansi lebih kecil dari 0,05 maka $\mathrm{H}_{0}$ ditolak dan $\mathrm{H}_{1}$ diterima. Berdasarkan Tabel 7. maka hasil pengujian secara parsial masing-masing variabel independen terhadap dependen dapat dijabarkan sebagi berikut.

Berdasarkan Tabel 8. nilai signifikansi sebesar $0,021<\alpha(0,05)$. Hasil ini menunjukkan bahwa kecerdasan emosional secara parsial berpengaruh positif dan signifikan terhadap tingkat pemahaman akuntansi pada mahasiswa nonreguler jurusan akuntansi angkatan 2014 Fakultas Ekonomi dan Bisnis Universitas Udayana.

Hipotesis pertama $\left(\mathrm{H}_{1}\right)$ dalam penelitian ini yaitu kecerdasan emosional berpengaruh positif pada tingkat pemahaman akuntansi. Hal ini menunjukkan semakin baik kecerdasan emosional, maka tingkat pemahaman akuntansi akan semakin baik. Hal ini berarti semakin tinggi kecerdasan emosional yang dimiliki oleh mahasiswa maka akan semakin baik pemahaman akuntansinya.Seorang mahasiswa yang memiliki kecerdasan emosional yang tinggi akan berdampak positif pada dirinya untuk mengetahui dan menanggapi perasaan mereka sendiri dengan baik dan mampu membaca dan menghadapi perasaan orang lain secara efektif. 
Ida Ayu Clara Agustin dan I Ketut Sujana. Pengaruh...

Hasil kuesioner menunjukkan bahwa item pernyataan pengenalan diri nomor tiga yaitu menyelesaikan tugas kuliah yang akan menjadi tanggung jawab meskipun tidak menyukainya mendapatkan skor total tertinggi yaitu sebesar 428 . Hal ini menunjukkan bahwa adanya tugas-tugas kuliah yang diberikan dapat meningkatkan pemahaman akuntansi mahasiswa. Hasil penelitian ini sejalan dengan penelitian yang dilakukan oleh Junifar (2015), Rusmiani (2017), dan Ariantini (2017) yang menyatakan bahwa kecerdasan emosional berpengaruh positif dan signifikan terhadap tingkat pemahaman akuntansi.

Berdasarkan Tabel 8. nilai signifikansi sebesar $0,042<\alpha(0,05)$. Hasil ini menunjukkan bahwa kecerdasan spiritual secara parsial berpengaruh positif dan signifikan terhadap tingkat pemahaman akuntansi pada mahasiswa nonreguler jurusan akuntansi angkatan 2014 Fakultas Ekonomi dan Bisnis Universitas Udayana.

Hipotesis kedua $\left(\mathrm{H}_{2}\right)$ dalam penelitian ini yaitu kecerdasan spiritual berpengaruh positif pada tingkat pemahaman akuntansi. Hal ini berarti semakin tinggikecerdasan spiritual, maka tingkat pemahaman akuntansi semakin meningkat.Hal ini berarti semakin tinggi kecerdasan spiritual yang dimiliki oleh mahasiswa, maka akan semakin baik pemahaman akuntansinya. Seorang mahasiswa yang memiliki kecerdasan spiritual yang tinggi akan mampu memaknai hidup dengan memberi makna positif pada setiap peristiwa yang dialaminya, berpikir logis, serta selalu yakin bahwa sesuatu yang dilaksanakan diimbangi dengan berdoa akan lebih percaya diri untuk belajar sehingga akan mudah memahami suatu materi yang dipelajari. 
Hasil kuesioner menunjukkan bahwa item pernyataan berpandangan holistik nomor empat belas yaitu selalu ada makna dibalik peristiwa yang saya alami mendapatkan skor total tertinggi yaitu sebesar 437. Hal ini menunjukkan bahwa mahasiswa yang selalu berpikir ada makna dibalik peristiwa yang dialaminya dan dapat berpikir secara logis dapat mempengaruhi pemahaman akuntansinya. Hasil penelitian ini sejalan dengan penelitian yang dilakukan oleh Ardewi dan Sujana (2017), Clarken (2010), dan Junifar (2015) yang memperoleh hasil kecerdasan spiritual berpengaruh positif dan signifikan pada tingkat pemahaman akuntansi.

Berdasarkan Tabel 8. nilai signifikansi sebesar $0,001<\alpha(0,05)$. Hasil ini menunjukkan bahwa perilaku belajar secara parsial berpengaruh positif dan signifikan terhadap tingkat pemahaman akuntansi pada mahasiswa nonreguler jurusan akuntansi angkatan 2014 Fakultas Ekonomi dan Bisnis Universitas Udayana.

Hipotesis ketiga $\left(\mathrm{H}_{3}\right)$ dalam penelitian ini yaitu perilaku belajar berpengaruh positif pada tingkat pemahaman akuntansi. Hal ini berarti semakin baik perilaku belajar yang dilakukan oleh mahasiswa, maka akan semakin baik pemahaman akuntansinya. Seorang mahasiswa yang memiliki pola belajar yang teratur akan menimbulkan intensitas belajar yang lebih tinggi serta lebih aktif dikelas dibandingkan dengan mahasiswa yang memiliki pola belajar yang tidak teratur. Perilaku belajar yang baik akan mengasah kemampuan berfikir dan meningkatkan penguasaan materi pelajaran yang dipelajari.

Hasil kuesioner menunjukkan bahwa item pernyataan kebiasaan mengikuti pelajaran nomor dua yaitu bekerja samadengan teman saat mengerjakan latihan 
Ida Ayu Clara Agustin dan I Ketut Sujana. Pengaruh...

mendapatkan skor total tertinggi yaitu sebesar 409. Hal ini menunjukkan bahwa berdiskusi bersama-sama dalam mengerjakan latihan dapat meningkatkan semangat belajar sehingga dapat meningkatkan pemahaman akuntansi mahasiswa. Hasil penelitian ini sejalan dengan penelitian yang dilakukan oleh Junifar (2015) dan Rusmiani (2017) yang memperoleh hasil perilaku belajar berpengaruh positif dan signifikan pada tingkat pemahaman akuntansi.

\section{SIMPULAN}

Berdasarkan pembahasan hasil penelitian di atas, dapat disimpulkan bahwa kecerdasan emosional, kecerdasan spiritual, dan perilaku belajar berpengaruh positif dan signifikan pada tingkat pemahaman akuntansi pada mahasiswa nonreguler jurusan akuntansi angkatan 2014 Fakultas Ekonomi dan Bisnis Universitas Udayana. Sedangkan saran yang dapat diberikan adalah bagi mahasiswa jurusan akuntansi nonreguler dapat ditingkatkan lagi perilaku belajarnya antara lain dengan cara mengikuti dan memahami setiap mata kuliah akuntansi yang diajarkan di kelas serta memperbanyak praktik-praktik dan studi kasus akuntansi sehingga akan meningkatkan pemahaman akuntansinya. Bagi peneliti selanjutnya diharapkan dapat menggunakan factor - factor lain yang dapat mempengaruhi pemahaman akuntansi seperti budaya dan kepercayaan diri serta dapat memperluas sampel dengan menggunakan sampel mahasiswa reguler dan nonregulerangkatan selanjutnya untuk memperoleh perbandingan hasil. 


\section{REFERENSI}

Abed, K. (2012). Interest in the Manaement Accounting Profession: Accounting Students' Perceptions in Jordanian Universities. Journal of Asian Social Science, 8(3), 303-316.

Abraham, H. M. (2010). Motivation and Personality. Jakarta: Rajawali.

Ariantini, K. T. (2017). Pengaruh Kecerdasan Emosional, Kecerdasan Spiritual, Dan Kecerdasan Sosial Terhadap Pemahaman Akuntansi Pada Mahasiswa Jurusan Akuntansi Program S1 Angkatan 2013 Universitas Pendidikan Ganesha. E-journal Akuntansi, 7(1).

Artana, M. B.(2014). Pengaruh Kecerdasan Intelektual (IQ), Kecerdasan Emosional (EQ), Kecerdasan Spiritual (SQ), dan Perilaku Belajar Terhadap Pemahaman Akuntansi. E-journalAkuntansi, 2(1).

Brackett, M., S. E. Rivers and P. Salovey. (2011). Implicational for Personal, Sosial,Academic, and Work Place Success.The Journal of Social and Personality Psichology Compass, 1(5), 88-103.

Cetin, B. (2016). Academic Motivation and Approaches to Learning In Predicting College Students' Academic Achievement: Findings From Turkish and US Samples. Journal of College Teaching \& Learning, 13(1), 21-28.

Clarken, R. H. (2010). Considering Moral Intelligence as Part of a Holistic Education. Journal Education, Northern Michigan University.

Dewi, N. P. R. A dan D. G. Wirama. (2016). Kepercayaan Diri Sebagai Pemoderasi, Pengaruh Kecerdasan Emosional dan Perilaku Belajar Pada Tingkat Pemahaman Akuntansi. E-jurnal Akuntansi, 16(1), 615-644.

Dwi, H., I. Immanuela., dan G. Widyawati. (2014). Pengaruh Kecerdasan Emosional, Perilaku Belajar dan Budaya terhadap Tingkat Pemahaman Akuntansi dengan Kepercayaan Diri Sebagai Variabel Moderating. Jurnal Riset Manajemen dan Akuntansi, 2(1), 25-34.

Fanikmah, D. A. (2016). Pengaruh Kecerdasan Emosional dan Minat Belajar terhadap Pemahaman Akuntasi. Jurnal Ilmu dan Riset Akuntansi, 5(7), 1-17.

Fred, P., S. Guina., and S. Alford. (2012). Illustration in Financial Accounting Textbooks: Function and Placement Interact to Affect Student Learning. Issues in Accounting Education, 27(4), 999-1017.

Goleman, D. (2011). KecerdasanEmosional. CetakankeDuaPuluhSatu. Jakarta: PT. GramediaPustakaUtama. 
Ida Ayu Clara Agustin dan I Ketut Sujana. Pengaruh...

Hakim, L. (2010). Pengaruh Kecerdasan Emosional terhadap Tingkat Pemahaman Akuntansi pada Mahasiswa Universitas Gunadarma. Jurnal Akuntansi.

Hanifah, S. A. (2001). Pengaruh Perilaku Belajar Terhadap Prestasi Akademik Mahasiswa Akuntansi. Media Riset Akuntansi, Auditing, dan Informasi, 3(1), 63-86.

Haryoga, S. dan E. Supriyanto. (2011). Pengaruh Kecerdasan Emosional, Perilaku Belajar, dan Budaya Terhadap Tingkat Pemahaman Akuntansi dengan Kepercayaan Diri Sendiri sebagai Variabel Pemoderasi. Simposium Nasional Akuntansi XIV.

Juliastantri, M. D. (2014). Pengaruh Kecerdasan Emosional, Kecerdasan Spiritual, dan Perilaku Belajar Terhadap Tingkat Pemahaman Akuntansi (Studi Empiris Mahasiswa Fakultas Ekonomi Jueusan Akuntansi Angkatan Tahun 2010 Universitas Jember). Artikel Ilmiah Akuntansi.

Junifar, N. (2015). Pengaruh Kecerdasan Emosional, Kecerdasan Spiritual, dan Perilaku Belajar Terhadap Tingkat Pemahaman Akuntansi. Jurnal Ilmu \& Riset Akuntansi, 4(10),1-20.

Khajehpour, M. (2011). Relationship Between Emotional Inteligence Parental Involvement and Academic Performance of High School Students.Procedia Social and Behavioral Sciences, 15, 1081-1086.

Khavari, K.A. (2000). Spritual Intelligence (A Pratictical Guide to Personal Happiness). White MountainPublications: Canada.

Laksmi, R. A. dan I. K. Sujana. (2017). Pengaruh Kecerdasan Intelektual, Kecerdasan Emosional, dan Kecerdasan Spiritual Terhadap Pemahaman Akuntansi. E-jurnal Akuntansi, 21(2), 1373-1399.

Lunenburg, F. (2011). Self Efficacy in the Workplace: Implications for Motivation and Performance. International Journal of Management, Business, and Administration, 14(1), 101-106.

Marita, S., H. Suryaningrum., dan S. Naafi. (2010). Kajian Empiris Atas Perilaku Belajar dan Kecerdasan Emosional Dalam Mempengaruhi Stres Kuliah Mahasiswa Akuntansi. Simposium Nasional Akuntansi IX. Pontianak.

Ronnel, N. (2008). The Experience of Spiritual Intelligence. The Journal of Transpersonal Psychology, 40(1). 
Rusmiani, N. K. A. (2017). Pengaruh Kecerdasan Emosional, Kecerdasan Intelektual, dan Perilaku Belajar Pada Tingkat Pemahaman Akuntansi (Studi Empiris Mahasiswa Nonreguler Jurusan Akuntansi Fakultas Ekonomi dan Bisnis Universitas Udayana). E-Journal Akuntansi, 20(2), 959-985.

Sahara, M. (2014). Pengaruh Perilaku Belajar, Kecerdasan Emosional, Kecerdasan Intelektual, Kecerdasan Spiritual, dan Kecerdasan Sosial Terhadap Pemahaman Akuntansi. Jurnal Ekonomi, 3(2), 35-44.

Sari, M. R., I. D. G. Dharma., dan N. L. Supadmi. (2015). Pemahaman Akuntansi, Profesionalisme dan Kinerja Pemeriksaan Pajak Pada KPP Pratama Se-Bali. Proceding Seminar Nasional Sains dan Teknologi, 589-596.

Triarina, H. F. dan R. Wardana. (2015). Pengaruh Perilaku Belajar, Kecerdasan Emosional, dan Kecerdasan Spiritual Terhadap Tingkat Pemahaman Akuntansi Pada Mahasiswa Jurusan Akuntansi Universitas Narotama Surabaya. JurnalAkuntansi, 1-8.

Trisnawati, E. I. dan S. Suryaningrum. (2003). Pengaruh Kecerdasan Emosional Terhadap Tingkat Pemahaman Akuntansi. Simposium Nasional Akuntansi $V I$.

Yani, F. (2011). Pengaruh Kecerdasan Intelektual, Kecerdasan Emosional, dan Kecerdasan Spiritual Terhadap Pemahaman Akuntansi. Jurnal Akuntansi Pendidikan. Universitas Riau.

Zohar, D. dan I. Marshall. (2001). SQ: Memanfaatkan Kecerdasan Spiritual dalam Berpikir Integralistik dan Holistik untuk Mamaknai Kehidupan. Bandung: Mizan Pustaka. 